\title{
Assistance and compensation to victims of trafficking
}

\author{
Article by Elizabeta Imeraj ${ }^{1}$ \\ Prosecutor of Serious Crime, Albania \\ Email:- fitorebytyqi@live.com
}

\begin{abstract}
According to international norm, the Declaration of Basic Principles of Justice for Victims of Crime and Abuse of Power, adopted by the General Assembly of the UN, is the international act fundamental, defining the rights of victims and procedures for compensation for damage to them. This paper promotes some of their rights to move up to the justice and fair treatment to them that among other things means legal assistance and information in time for all aspects of procedural, restitution, compensation of damage, putting in place rights, etc., the compensation from the state when the offender funds are insufficient for this etc.

Besides compensation from the trafficker, there is another way to compensate the victim, through a public scheme. In our domestic legislation that provided for in Law no. 10192, dated 3.12.2009 "On prevention and suppression of organized crime and trafficking through preventive measures against assets".

Through the work of this analysis will be addressed through legislation compensation, indemnification and above all contributions awarded to victims of human trafficking:
\end{abstract}

Keywords: relief, damages, legislation, compensation, trafficking of human beings

\section{Protection and assistance to victims of trafficking}

Similarly, the Convention of the United Nations Convention against Transnational Organized Crime and its additional Protocol, the so-called Palermo Protocol to prevent, suppress and punish trafficking in persons, especially women and children, stipulate the obligation of States Parties, which depending national law, enable the views and concerns of victims to be present and to be considered at appropriate stages of the investigation procedures $^{2}$. Article 6, paragraph 2 of the Protocol, establishes the obligation of states to provide assistance to victims of trafficking through such measures that provide victims of trafficking in appropriate cases, information about court proceedings, assistance in order to present concerns and problems and the steps to be taken into account relevant criminal proceedings against offenders, without prejudice to the right of defense ${ }^{3}$.

Meanwhile, the Council of Europe Convention "On Measures against Trafficking in Human Beings" in 2005 compared to other international instruments in the fight against trafficking in human beings has at its center the human rights and protection of victims. The Convention defines trafficking as a violation of human rights and violation of human dignity and human integrity.

Regarding the scope of the Convention, it covers all forms of trafficking, whether national or across borders, linked or not to organized crime, all victims of trafficking (women, men and children), all forms exploitation (sexual, forced labor or services, slavery, the removal of organs). This Convention is the first international legal instrument that gives the definition of "victim of trafficking in human beings'.

\footnotetext{
${ }^{1}$ Tirana, Albanai, Prosecution of Serious Crimes-Tirana,

${ }^{2}$ Law no. 8920, dated 11.7.2002, "On the ratification of the UN Convention against Transnational Organized Crime and its two additional protocols", paragraph 3 of Article 25 "Support and protection of victims' Convention

${ }^{3}$ Law no. 8920, dated 11.7.2002 "On the ratification of the UN Convention against

Transnational Organized Crime and its two additional protocols", paragraph 2, Article 6

"Assistance for the protection of victims of trafficking in persons"
} 
South American Journal of Academic Research

Special Edition May 2016

Under Article 28 of the EC Convention victim should be guaranteed the right to be protected from potential retaliation or intimidation, in particular during and after investigation and prosecution of traffickers. That's right, if necessary, applies to those who report criminal offenses of trafficking in persons or to cooperate with authorities in the investigation or criminal proceedings, as well as witnesses to give evidence and, if necessary, members of their family. Protection may include physical protection, relocation, identity change and assistance in finding a job. Concerning children, section defines special protective measures in the best interest of the child.

The situation is different in the Albanian criminal legislation. Our system is an accusatory system, so there are in the spotlight of the offender and the sole purpose of criminal sanctions are the author's detention, prevention of commission of criminal offenses by others, and the rehabilitation of the author through the penitentiary system. While the restitution and compensation of victims does not constitute in itself the purpose of the criminal sanction ${ }^{4}$. Albanian Criminal Code in its general part does not recognize the term "victim" as this part focuses mainly on general concepts of crime, criminal liability and criminal sanctions, while the Code special deals with specific offenses. T his means that the victim does not appear as a separate entity, independent of the criminal law, as such it does not have standing as a party in criminal proceedings as the prosecution, the defendant and the court.

While the Code of Criminal Procedure mention the term "person aggrieved". ${ }^{5}$, through which the injured party is known as the subject procedural figures offense and defective material from the offense, which among them are not provided trafficking offenses, Article 110 /a "Trafficking of adults" and Article 128 /b "Trafficking minors ", thereby excluding the right of trafficking victims to legitimize the subject of separate proceedings. For these reasons nowadays under criminal procedural victims of trafficking are not directly involved in the criminal process as a party "cannot achieve its fundamental rights to participation, protection and restitution".. .

As part of the continuing review of domestic legislation to bring it in line with international norms mentioned above, in May 2013 Criminal Code underwent some changes, which aimed at harmonizing the provisions of the Code on offenses of trafficking in human beings Convention obligations EC. Specifically, regarding the provision on non-punishment of trafficking victims, the new Article 52 / a "Exemption or reduction of sentences for collaborators of justice and victims" of the Criminal Code $^{7}$ It establishes the possibility of exemption from serving the sentence or reduce its victims of trafficking if charges and helps makes legal prosecution of the offense of trafficking in persons. Although the introduction of Article 52 / a of the Criminal Code can be considered a positive step in the protection of victims of trafficking, again, this article is only partially compliant with the standard required by the Convention, since it connects the exemption from punishment of the victim by giving charges or collaborating with justice. From the interviews conducted by prosecutors it shows that in cases where the victim refuses to provide narration or statement about her trafficking or exploitation, initiated criminal proceedings dismissed and when they are used for prostitution in the event of non-testifying prosecute prosecuted for prostitution. ${ }^{8}$

\footnotetext{
${ }^{4}$ Sander Simon "The treatment of trafficking victims as witnesses during the trial. Legal options for compensation of victims of trafficking and the need for legal changes. Problems encountered in judicial practice. "Tirana, February 2013

${ }^{5}$ Law No. 7895, dated 27.1.1995 "Criminal Code of the Republic of Albania", as amended, Article 58 "The rights of the victim of crime" and Article 59 "The injured accuser"

${ }^{6}$ Sander Simon "The treatment of trafficking victims as witnesses during the trial. Legal options for compensation of victims of trafficking and the need for legal changes. Problems encountered in judicial practice. "Tirana, February 2013

${ }^{7}$ Penal Code, Article 52 / or adding to the law 144/2013, dated 05/02/2013, Article 7

${ }^{8}$ Criminal Code, Article 113 "Prostitution"
} 
Regarding the impact of prevention and other crimes that facilitate trafficking in the new article 110/b of the Criminal Code ${ }^{9}$ re provision of benefits or use of services provided by victims of trafficking with imprisonment of 2-5 years and when the victims are children from 3-7 years imprisonment. With the new provisions, in accordance with Article 6 of the Convention of E Caim of demand-side shock, as a preventive measure against trafficking.

Another change to the Criminal Code concerning acts of trafficking is the introduction of Article 110/c, which is defined as a criminal act and actions that facilitate the trafficking of adults as "counterfeiting, possession or provision of identity documents, passports, visa or other travel documents or retention, removal, concealment, damage or destruction "10, which is punishable by 2-5 years and in case of facilitation of child trafficking is punishable by 4-8 years. Although the legislature has sought to harmonize the Penal Code with the Convention ECas regards the provisions of substantive criminal law, yet in this article there is confusion as regards the scope of performance of the actions mentioned above, the purpose of trafficking persons.

While in terms of protection that provide special legislation, the new law for "foreigners" of 2013, in paragraph 1 of article 54 "The issuance of residence permits to victims of human trafficking "provides for a period of reflection and recovery 3 months for victims of trafficking foreigners to leave the influence of traffickers and to explore the possibility of cooperation with the authorities responsible for the investigation of criminal trafficking. T his is possible through the device with a residence permit for a period of 3 months, regardless of the will of his /her to cooperate with justice, when there are reasonable grounds to believe that the alien is a victim or potential victim of trafficking, the identified as such by the structures responsible for the identification and referral of victims of trafficking. T his permit is given to the victim or potential victim of trafficking in order to recover, and treated by physical and mental condition for obtaining a knowledgeable decision to cooperate or not with justice. During this period, they enjoy all the rights as victims of trafficking under applicable law. ${ }^{11}$

Also, a special protection was offered to victims of trafficking as protected witnesses based on the Law on "protection of witnesses and collaborators of justice"12. This law has become the definition of "person protection or" witness to justice ". "Witness of justice", according to this law, a person who, as a witness or the injured person makes statements or testifies to facts and circumstances that constitute evidence in a criminal proceeding and that, because of these statement or testimony is in a dangerous situation. Victims of trafficking can appear frequently in this procedural position, but so far in this program is included only a victim of trafficking in $2011^{13}$.

When victims of trafficking appear as witnesses in providing evidence or testimony are accompanied police officers to the Serious Crimes Court, assisted by representatives of various organizations that conduct activities in this field.

Special measures for protection of witnesses apply where the application of the ordinary measures of witness protection justice is not sufficient and appropriate, the person admits cooperate freely with the prosecution and the Court of Serious Crimes as through his testimony complete, made without conditions and reservations, provides data based constituting evidence related to a criminal investigation for serious crimes, assist in preventing the commission of a serious crime or reduce the consequences arising from their help repair the damage and losses caused by the commission of serious crimes.

\footnotetext{
${ }^{9}$ Criminal Code, Article 110 / b "benefit or use of services provided by persons trafficked"

${ }^{10}$ Criminal Code, Article 110 / c "Actions that facilitate trafficking," added Law nr. 144 / 2013 "On amendments and additions to Law No. 7895, dated 27.1.1995" Criminal Code of the Republic of Albania "amended" in Article 27

${ }^{11}$ Law no. 108/2013 "For foreigners", points 1 and 2, Article 54

${ }^{12}$ Dt. 415.03.2004"Për 9205 law protecting witnesses and collaborators of justice '

${ }^{13}$ ONAC Report on the Implementation of the National Plan of Action against Trafficking in Persons, 2011
} 
South American Journal of Academic Research

Special Edition May 2016

Implementation of special measures of protection of the witness only if he is placed in a real, concrete and serious, it is convenient to be involved with these measures, with their free will accept and actively participates in the implementation them. Special measures of protection for witnesses, collaborators of justice and persons close to or related with them are those dealing with the change of identity, residence, temporary protection of identity, data and documents of the protected person, declarations of a witness under another identity and their administration with special means for voice distortion, true to his appearance and other forms defined by law.

Also, Article 8 of the law "On the organization and functioning of the Court of First Instance for Serious Crimes"14 It provides that the courts for serious crimes and the Court of Appeal for Serious Crimes may allow the questioning of witnesses, as well as confrontations and permissible readings be applying, together or separately, the following rules: a) the presence of the defendant and defenders, but without visual contact; b) without communicating the defendant and the witness's identity; c) in other cases and manner specified by the legislation on the protection of witnesses and collaborators of justice ${ }^{15}$.

Other important rules for the protection of witnesses under Article 361/A-1 of the Code of Criminal Procedure. According to this article, the question of protected witnesses can be conducted at a distance via audiovisual connection, according to the rules laid down in Article $361 / 7$ of the Code of Criminal Procedure. These are guarantees effective and feasible treatment and protection of victims of trafficking under the required conditions. ${ }^{16}$

- The position of the victims of trafficking in the trial of offenses of trafficking

As mentioned above, the issue of positioning problems of a victim of trafficking in the process of investigation and trial as a witness where the competent Court for Serious Crimes ${ }^{17}$ It related to the lack of legal provisions positioning of the victim as a party in the role of a witness unless procedural or civil plaintiff for pecuniary damage.

When the victim came to the witness stand in most cases, as noted during the interview prosecutors proceeded to the evidence ${ }^{18}$ the statements of the victims/witnesses in the preliminary investigation stage. $\mathrm{T}$ his measure is taken because often give victims the report and during the trial when they appear as a witness in proceedings against traffickers, represent another situation due to intimidation by traffickers. During the hearing of securing evidence

\footnotetext{
${ }^{14}$ Law no. 9110, dated 24.07.2003 "On the organization and functioning of the Court of First Instance for Serious Crimes"

${ }^{15}$ Law no. 9110, dated 24.07.2003 "On the organization and functioning of the First Instance Court for Serious Crimes," Article 8 "question witnesses

${ }^{16}$ Sander Simoni: "The treatment of trafficking victims as witnesses during the trial. Legal options for compensation of victims of trafficking and the need for legal changes. Problems encountered in the judicial practice. "Tirana, February 2013

${ }^{17}$ Article 74 of the Code of Criminal Procedure It provides on subject matter jurisdiction of the district court judgment of those offenses that do not belong to the competence of the court for serious crimes and the High Court. While, under Article 75 / a "The powers of the Court for Serious Crimes" of the Code of Criminal Procedure, the Court for Serious Crimes has under its jurisdiction the trial of 33 offenses, which would include the prosecution of criminal acts of trafficking, namely Article 110 / a and Article 128 / b envisaged by the Criminal Code. Thus, the judgment of the offense of exploitation of prostitution, pursuant to Article 114 of the Criminal Code, does not rank among the criminal trial which is Gj. KR's competence, hence in accordance with Article 74, "The powers of the district court "Code of Criminal Procedure of the criminal trial is the competence of the district court proceedings.

${ }^{18}$ Code of Criminal Procedure, Article 316 "Security Test Cases"
} 
for these witnesses is applied Article 8 of the law "On the organization and functioning of courts for serious crimes "by asking without visual contact". ${ }^{19}$

From the case law of the Supreme Court concluded that during the questioning of victims at a time when they are considered as damaged by criminal acts to law enforcement in general have not applied their right under Article 158 of the Procedure Code P. for exemption from the obligation to testify, leading to dissolution of the injunction because the administration of proof in violation of criminal procedural $\mathrm{law}^{20}$. Similarly, Article 158/C/2 of the Criminal Procedure Code provides that it is not obliged to testify who, though not the defendant's spouse, cohabiting or has cohabited with him. The logic of lawmakers in the drafting of this provision has been the preservation of the principles of a socially important, as is that between spouses or cohabitants, excluding this about subjects from having to testify at trial of criminal proceedings dependent on their relatives, about events and facts on which they are aware. In particular, the legislator has recognized a special status spouse, former spouse, partner or person associated with the adoption of the defendant in a criminal proceeding, making it mandatory for the body of procedure in any case, even when the charge of the work of It is made of these subjects at the time of administration of the evidence they need to be made known right not to testify. In this way, the legislator has separated itself this about subjects other persons provided by article 16, which, despite the connection to the defendant, as long as the predicates in quality cannot be exempted from having to testify. ${ }^{21}$

\section{Indemnity and compensation of victims}

Legislation does not exist a special law for compensation and reparation for victims. The only possibility that victims under criminal procedural law to compensation for the damage that was caused is through a civil lawsuit in the criminal process. The civil lawsuit in the criminal process provided for in Article 61 of the Criminal Procedure Code ${ }^{22}$ and entitles the victim as a civil plaintiff, require through a civil action in the criminal proceedings against the trafficker or civil defendant, property restitution and compensation. Also, victims of trafficking may file a separate civil suit in civil court by referring to Article 647 /a of the Civil Code, the remuneration of non-pecuniary damage. The civil lawsuit, provides protection for the victim because her request as civil plaintiff, the proceeding in order to ensure the return of property and compensation for the damage, impose seizure of property of the defendant or civil defendant. $\mathrm{T}$ his measure stands until the end of the matter ${ }^{23}$.

In case the court gives a decision of acquittal for the defendant, because the fact is not provided as a criminal offense, or when the decision to terminate the criminal case, the civil lawsuit left unexamined denying thereby the victim the right to compensation. Another drawback is the fact that procedural civil lawsuit in the criminal process can be used under Article 61 of the Code of Criminal Procedure only for pecuniary and non-pecuniary damage not by depriving victims of their right to seek compensation of non-pecuniary damage in a criminal process. As noted above, this right can be enjoyed by direct indictment in civil court, claim that this court has. "Problems of cost, time and the outcome uncertain"24.

Besides compensation from the trafficker, there is another way to compensate the victim, through a public scheme. In our domestic legislation that provided for in Law no. 10192, dated 3.12.2009 "On prevention and suppression of organized crime and trafficking through preventive measures against assets". Specifically, Article 37 of the law stipulates the

\footnotetext{
${ }^{19}$ Sander Simoni: "The treatment of trafficking victims as witnesses during the trial. Legal options for compensation of victims of trafficking and the need for legal changes. Problems encountered in judicial practice ", Tirana, February 2013

${ }^{20}$ Code of Criminal Procedure, Article 151/4 "Taking of evidence".

${ }^{21}$ Decision no. 555 of the Criminal Panel of the Supreme Court, page 8.

${ }^{22}$ Code of Criminal Procedure, Article 61 "civil lawsuit in the criminal process".

${ }^{23}$ Code of Criminal Procedure, Article 63 "Providing civil lawsuit."

24 "Compensation for trafficked persons and exploited in the OSCE region", OSCE, Warsaw 2008
} 
South American Journal of Academic Research

Special Edition May 2016

establishment of a Special Fund for the Prevention of Crime, which serves among other things, to come to help victims of crime, including victims of trafficking, and to promote social programs for this category. This provision is in accordance with paragraph 4 of Article 15 of the EC, which provides for sanction by the domestic law of the parties, the establishment of a fund for victim compensation or measures or programs of compensation, aimed at protection and social integration victims, programs that may be financed by assets confiscated traffickers. On the other hand, in practice the implementation of this provision is found to be less effective, because the law has not directly predict how a victim of trafficking can benefit from this fund, through administrative or penal process and civil.

According to professionals in the field, the most efficient way to guarantee this right victims would be simultaneous judgment of the author, trafficker and lawsuit seeking compensation, as this would facilitate the victim psychologically and reduce procedure and costs. This is supported and the findings of a study of the OSCE on compensation for trafficked persons and exploited, which state that "to prove the damage by evidence of victimization past and present, as well as names or definitions of certain categories of damage as "loss of dignity" may re-traumatizing effect on the trafficked person " 25 .

Also, compensation to the victim could be done by determining the compensation as part of major penalty against the trafficker, the main aim being to compensation from the offender, who has caused the damage and the suffering of the victim.

\section{Conclusions}

Our system is an accusatory system, so there are in the spotlight of the offender and the sole purpose of criminal sanctions are the author's detention, prevention of commission of criminal offenses by others, and the rehabilitation of the author through the penitentiary system. While the restitution and compensation of victims do not constitute in itself the purpose of the criminal sanction. Albanian Criminal Code in its general part does not recognize the term "victim" as this part focuses mainly on general concepts of crime, criminal liability and criminal sanctions, while the Code special deals with specific offenses. This means that the victim does not appear as a separate entity, independent of the criminal law, as such it does not have standing as a party in criminal proceedings as the prosecution, the defendant and the court.

While the Code of Criminal Procedure mention the term "person aggrieved", through which the injured party is known as the subject procedural figures offense and defective material from the offense, which among them are not provided trafficking offenses, Article 110 /a "Trafficking of adults" and Article 128 /b" Trafficking of Minors", thereby excluding the right of trafficking victims to legitimize the subject of separate proceedings.

Legislation does not exist a special law for compensation and reparation for victims. The only possibility that victims under criminal procedural law to compensation for the damage that was caused is through a civil lawsuit in the criminal process. The civil lawsuit in the criminal process provided for in Article 61 of the Criminal Procedure Code and entitle the victim as a civil plaintiff, require through a civil action in the criminal proceedings against the trafficker or civil defendant, property restitution and compensation. Also, victims of trafficking may file a separate civil suit in civil court by referring to Article 647 / a of the Civil Code, the remuneration of non-pecuniary damage.

\section{Literature}

[1] Sander Simon "The treatment of trafficking victims as witnesses during the trial. Legal options for compensation of victims of trafficking and the need for legal changes. Problems encountered in judicial practice.

"Tirana, February 2013

[2] Criminal Code, Article 113 "Prostitution"

25 "Compensation for trafficked persons and exploited in the OSCE region", OSCE, Warsaw 2008 
[3] Criminal Code, Article 110/b "benefit or use of services provided by persons trafficked"

[4] Criminal Code, Article 110/c "Actions that facilitate trafficking, "added Law nr. 144/2013 "On amendments and additions to Law No. 7895, dated 27.1.1995 "Criminal Code of the Republic of Albania "amended" in Article 27

[5] Law no. 108/2013 "For foreigners", points 1 and 2, Article 54

[6] Dt. 415.03.2004 "Për 9205 law protecting witnesses and collaborators of justice ”

[7] ONAC Report on the Implementation of the National Plan of Action against Trafficking in Persons, 2011

[8] Code of Criminal Procedure, Article 316 "Security Test Cases"

[9] Decision no. 555 of the Criminal Panel of the Supreme Court, page 8.

[10] Code of Criminal Procedure, Article 61 "civil lawsuit in the criminal process".

[11] Code of Criminal Procedure, Article 63 "Providing civil lawsuit."

[12] Compensation for persons trafficked and exploited in the OSCE region, OSCE, Warsaw 2008

[13] Code of Criminal Procedure, Article 151/4 "Taking of evidence".

[14] Law No. 7895, dated 27.1.1995 "Criminal Code of the Republic of Albania", as amended, Article 58 "The rights of the victim of crime" and Article 59 "The injured accuser"

[15] Law no. 8920, dated 11.7.2002, "On the ratification of the U N Convention against Transnational Organized Crime and its two additional protocols", paragraph 3 of Article 25 "Support and protection of victims' Convention

[16] Law no. 8920, dated 11.7.2002 "On the ratification of the U N Convention against Transnational Organized Crime and its two additional protocols", paragraph 2, Article 6 "Assistance for the protection of victims of trafficking in persons"

[17] Law no. 9110, dated 24.07.2003 "On the organization and functioning of the Court of First Instance for Serious Crimes"

[18] Law no. 9110, dated 24.07.2003 "On the organization and functioning of the First Instance Court for Serious Crimes, "Article 8 "question witnesses

[19] Penal Code, Article 52 /or adding to the law 144/2013, dated 05/02/2013, Article 7 